\title{
Traditional Sasak Women's Wear: An Ontological Analysis
}

\author{
Babat Nufus Tarenaksa $\mathrm{S}^{1^{*}}$ I Wayan Suardana ${ }^{2 * *}$, Aminah Fitria Marinda ${ }^{3 * *}$
}

\author{
Yogyakarta State University, Yogyakarta, Indonesia \\ *Corresponding author, Email: babatnufus@gmail.com \\ **Corresponding author,Email: wayan_suardana@uny.ac.id \\ ***Corresponding author, Email: aminah.afm@gmail.com
}

\begin{abstract}
Lambung is the daily wear of Sasak women in ancient times. This study finds that currently, Lambung is only used at certain occasions, such as traditional social ceremonies or events like weddings, circumcision ceremonies, cultural events, and others. The characteristics of Lambung traditional wear have inherent meanings or values. Data were taken constructively and the analysis was focused on the usability of the attire (ontology). The research findings reveal that Lambung can be analyzed through ontological approach to examine the extent of the changes that occur in the traditional clothing of Sasak women.
\end{abstract}

\section{Keywords: Traditional wear, Sasak tribe, Ontolog}

\section{INTRODUCTION}

The diversity of traditions and cultures that exist in each region would not necessarily be present without function, because actually culture and tradition are the identity of each region that gives birth to an inherent character [1]. Culture is a symbolic dimension and expression of people's lives. Lombok Island is inhabited by people who are predominantly Sasak. Sasak is a native tribe of Lombok Island. The Sasaknese have a variety of cultures and arts, such as folklore, dances, musical instruments, traditional ceremonies, and even traditional wear or clothing inherited from their ancestors in ancient times [2]. Traditional wear is one of the identities or characteristics of the people who wear it. Besides, traditional wear is also the official clothing of a certain area [3]. Meanwhile, tradition is a regulation that is implemented from generation to generation in the form of a hereditary regulation or a regulation made based on the prevailing norms.

From the above explanation, it can be concluded that traditional wear is a symbol of each region that makes the area has an identity that is preserved for generations through local cultural traditions. In addition, clothing is a necessity that is mandatory and must be fulfilled by the community in which the function of clothing is for the covering of the body and symbols of politeness or akhlak.

There are three types of traditional wear native to Sasaknese in Lombok Island, namely Pegon (for men), Kebaya (for women), and Lambung (for women). Lambung is the oldest form of Sasaknese women's wear, while Kebaya comes afterward. Lambung has different characteristics compared to Kebaya. Sasaknese wear is usually black in color and is combined with Bebet (patterned fabric functioning as a belt) and Songket as the sarong for men. For women, closednecked kebaya is often combined with long cloth or skirt. Lambung is used to be the daily wear of Sasaknese women, but nowadays this tradition has shifted as time goes by. The main function and original color of this traditional wear have changed, threatening the identity of Sasaknese over time. To solve the above problems, a theoretical and empirical ontological analysis is very much needed to describe findings on field. Ontology is one of the branches of philosophy that examines the meaning, property, and relation of an object that might happen in a certain domain of knowledge [4]. Ontology is very important to shed light on the structures of a discipline. In this case, ontology functions as a theory to examine the extent to which traditional wear of Sasaknese women has changed in terms of its functions and characteristics.

\section{METHOD}

This research was qualitative in nature employing phenomenological approach. The researchers carried out some observations and interviews to obtain data concerning the factors causing the changes in the traditional wear of Sasaknese women and the extent to which these changes had taken place.

In qualitative research, the data are presented in words not numbers. These data are obtained through observations, interviews, and document analysis [5]. In this study, the data were obtained through those three techniques. The observations were carried out through direct observation of the use of the traditional wear and the changes happened to 
them. The next was interviewing the culturists to find out more information on Lambung clothes with the original characteristics of the Sasak tribe and responses related to changes in the characteristics and reasons of people who wear the clothes as contaminated by the moves of postmodernism.

\section{RESULTS AND DISCUSSION}

Sasak traditional clothing is divided into three categories, Pegon for men, and Kebaya and Lambung for women [6]. This is also the same as the statement of H. Jalaludin Arzaki. However, this study will be more about discussing the development of Lambung that has changed in its characteristics and functions because it features the older Lombok costume than recent Kebaya, and because Lambung fabric is also recognized by the Sasaknese as their identity. The uniqueness of the Sasak traditional clothing certainly cannot be separated from the influences of external factor, especially the effect of cultural acculturation of Java, Bali, and Bugis. If seen from a historical background in the past, the spread of Islamic religion brought by the Javanese people can be seen from the evidence or style of the development of literary works composed by the language of Central Javanese and developed by using Macapat songs. Besides, Lombok was also influenced by the war occurred between the Sasak and Bali Tribe in ancient time, which of course, had a big impact on the shifting characteristics of arts and culture in Lombok, as explained in the book Sejarah Daerah Nusa Tenggara Barat (the History of the West Nusa Tenggara Region). [7].

In the development of kingdoms in Java and Sulawesi followed by wars and executions among them due to the crystallization by Hindu-Buddhist syncretism and the spread of Islamic religions, there exists the mobility from North to South and from West to East that later let West Nusa Tenggara become the latest foundation of various mobility. This proves the influence of Javanese, Sulawesi (Bugis), and Balinese culture on the culture of Lombok in West Nusa Tenggara. Another view [6] explains that, Lambung traditional clothes were born in the process of acculturation of Bugis as brought through the Samawa tribe on the island of Sumbawa in which Bugis had ruled the region for 4 centuries since the 16th century and then the culture spread to Lombok, and thus, through this acculturation, the impact especially for women's traditional clothes of Sasak emerged [8]. Acculturation is a social process that arises when a group of people with a particular culture is confronted with elements of a foreign culture in such a way that the foreign cultural elements are gradually accepted and processed into the home culture without causing loss of cultural identity. Acculturation can also be interpreted as a mixing of two different cultures so that it gives birth to a new culture from the results of the integration that occurs but people can still adopt the previous culture. Through such acculturation, Lambung exists and eventually becomes a symbol of Sasak on the island of Lombok with some other regions, and all of that was based on customary agreements. Figure 1 depicts Bugis and Sasak traditional clothes in which some similarities between them are found in terms of the overall form. There seems to be little difference in both, except that the traditional clothing of Bugis is longer in its lower part, while the Sasak's has undergone modification and is shorter but still appropriate in terms of what the Islam religion requires for women wear.
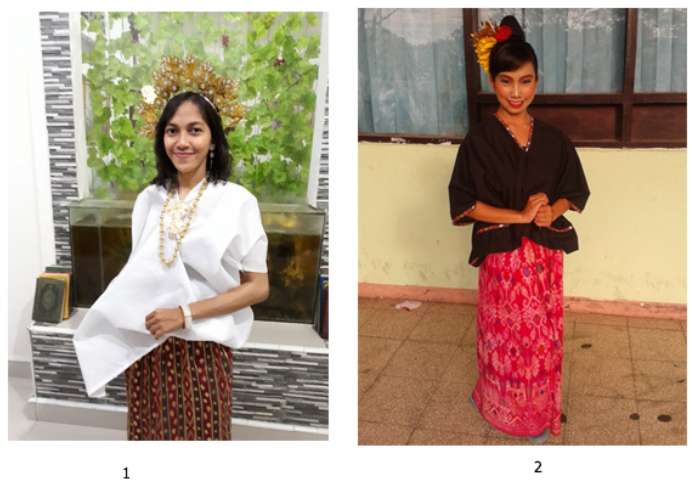

Fig. 1. Baju Bodo from Bugis (1) and Baju Lambung from Sasak with its original characteristics (2) (Source: Andi Rahmaeni \& Diany Asritishia, 2019).

It should be noted that this paper puts more concern on the changing of characteristics and functions of the Sasak Tribe women's wear (Lambung). It has specific shape on its V neck, black color, and some motifs on the neck, sleeves, and several other parts. Lambung in ancient times was used by Sasak women in their daily lives with the aim of covering their aurat - private parts of the body that cannot be exposed or should be covered according to Islam - and for traditional social purposes. The characteristics of the black Lambung has its own philosophy for the Sasaknese, in which in this dark color, humans must obey the rules of god and modest to God. This is because human beings were created by the God and can never be separated from black and dark sin and that being clean-white and purity only belongs to the creator, the God.

In the use of traditional clothing, Sasak women have some prohibitions that must not be violated, such as the following [6].

- Wearing transparent/translucent kebaya clothes;

- Using a gold-lined fabric (berprada);

- Betekek (using a shawl as a belt, except for cotton or leather belts or gendit (girdles);

- Using sumping (ear jewelry (shaped like a picture of wings made of leather and so on) and using camben (bekemben) - a female torso wrap - without kebaya;

- Using plain yellow shawl and cloth from sateen and other fabrics, which are black-white-checkered or poleng;

- Using open and transparent "kuta baru" kebaya;

- Using sumping, particularly using red roses;

- Use flip-flops on formal occasions;

- Using above-knee skirts or cloth.

With regard to the development of technology, a significant impact on the needs and desires of the community to create something different, endless creations, has resulted in a 
change in characters from the color of the traditional black Lambung to various colors and patterns as presented in the picture below.
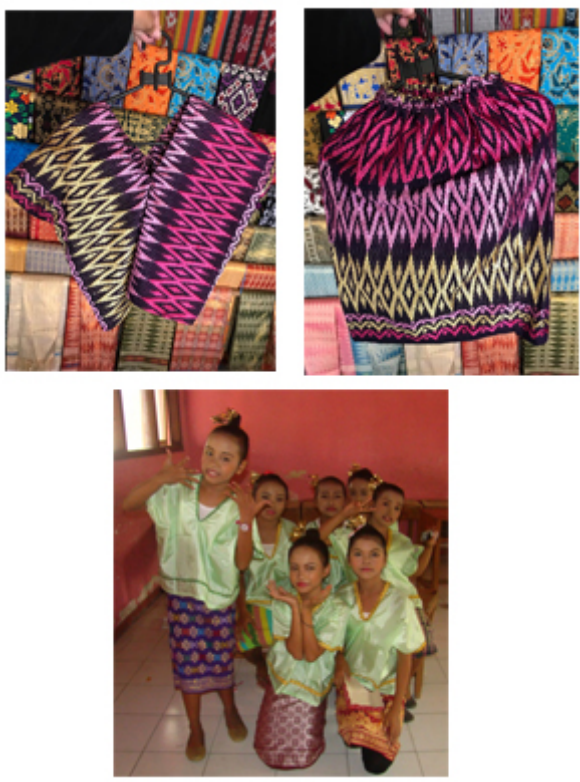

Fig. 2. Traditional Lambung that has undergone some changes in its characteristics (Source: Diany Asritisthia, 2019)

Changes in Sasak women's traditional wear can be seen from the clothes, in terms of colors that were previously pitch black to various colors such as pink, green, purple, red, yellow and even patterned but none of that leaves their original form. However, the changes resulted from this certainly affect the philosophy and value of the Sasak tribal women's traditional clothing. Besides, this change does not rule out the possibility of a shift in the identity of the Sasak community. One of the reasons for changing the characteristics of Sasak women's traditional clothing is a shift in the postmodern era where new thoughts begin to develop. Postmodernists may usually adopt or take an object or visual that already exists and then develop it into such a new one, which we can see from the feature or tendency of postmodernism. These postmodernist trends include eclecticism, ambiguity, understanding, playing with past forms in imitations (pastiche) [9]. It can be understood as the desire to show something different than usual, or those who want to bring out variations outside the normal. Therefore, people began to produce clothes with a variety of colors and patterns to produce a variety of clothing products.

In addition to color changes that occur in traditional Lambung, a shift in function also follows in which formerly it can be worn in the daily lives of Sasak women, ranging from children, adolescents, adults, to the elderly, but currently, they only wear it for certain events restricted to faith, such as wedding ceremonies, cultural marches, rites, and traditional events, and all of that cannot be separated from the effect of the postmodernism era [9]. That postmodern art, later, can probably be seen as a result of the ICT development in today's society. On the other hand, postmodernism can also be said as a critique of the concept of comprehensive knowledge without distinguishing who thinks, of the existence of the object of the tradition being studied, foundationalism or modernism [10].

Indubitably, the changes in the function of Lambung also have to do with changes in the characteristics of traditional clothing which starts from a matter of taste and sense of worth from the community in viewing their daily lives. This is similar to what a culturist from Lombok, H.L. Agus Faturahman, suggests during an interview on July 17, 2019, he explained one of the factors shifting the characteristics of traditional Lambung is the sense of appropriateness to use it, both ethically and aesthetically, and the development of fashion by paying attention to the sense of aptness. Thus, it can be assumed that the era of globalization have changed the patterns of thoughts and the needs and desires of the community so that Sasaknese has grown into a plethora of ideologies that could not be separated from the issue of appropriateness to appear in the general public.

This is in line with Opi Putri Andiyanti as one Sasaknese who argues related to changes in function that occur in traditional Lambung as interviewed on September 20, 2019. She adds that in terms of the function of the wear itself, it is now far from possible to use these clothes every day. This is due to adjusting to the era that now there are many choices in terms of clothing with a variety of diverse designs and colors, while in the past, such a choice to wear clothes might be limited, or maybe only Lambung clothes were available. Instead of forcing them to wear traditional clothes on a daily basis, which later will be the subject of the talk by the community members, people can have their own choices, except for traditional and cultural events. From the results of observations and interviews, it seems that most of the ideology of Sasak society has begun to be influenced by the rapid progress of the times.

\section{CONCLUSIONS}

Traditional Lambung clothes, in terms of its form, have been influenced by Bugis culture as spread through the Samawa tribe on the island of Sumbawa which had been ruled for 4 centuries since the 16th century. The culture was then spread to Lombok and went through the acculturation process so that it affected mainly on the traditional clothing of Sasak women. At the moment the traditional Lambung wear is experiencing a shift in function and color, but the changes do not leave its original form. Changes in characteristics, unfortunately, transform the meaning of the clothing itself. In addition to changing colors, traditional wear also changes its function, where today the society is influenced by the postmodern era causing the ideology of the community more developed. Since avoiding technological development is impossible, it is expected that Lombok people will not abandon the traditional clothing characteristics that are already well accepted, that Lambung with black color must continue to be preserved and produced, and to be appreciated for the values inherent therein. 


\section{REFERENCES}

[1] Kuntowijoyo, Metodologi Sejarah [Historical Methodologies]. "Yogyakarta: PT." Tiara Wacana Yogya (2003).

[2] Koten. dkk, Pakaian Adat Tradisional Daerah NTT [Traditional Clothing of East Nusa Tenggara]. Yogyakarta: Depertemen Pendidikan dan Kebudayaan, (1991):22

[3] Ali, Kamus Besar Bahasa Indonesia [Indonesian Dictionary]. Jakarta: Balai Pustaka, (1991):716.

[4] Chandrasekaran, Balakrishnan, John R. Josephson, and V. Richard Benjamins. "What are ontologies, and why do we need them?." IEEE Intelligent systems 1 (1999): 20-26.

[5] Rohidi, Tjetjep Rohendi. "Metodologi penelitian seni [Art Research Methodologies]." Semarang: Cipta Prima Nusantara 75 (2011): 116-121.
[6] Arzaki H Jalaludin. Busana Adat Sasak [Traditional Sasak Clothing]. KSU "Prima Guna", unpublished 2014, pp.3-5, dan 55.

[7] Suwondo, Bambang. Sejarah Daerah Nusa Tenggara Barat [The History of West Nusa Tengggara. Proyek Penelitian dan Kebudayaan Daerah Depertemen Pendidikan dan Kebudayaan: Jakarta, 1977/1978, pp.1-2

[8] Koentjaraningrat. "Pengantar Antropologi I [Introduction to Anthropologies I]." Jakarta: PT. Rineka Cipta, (2009):202.

[9] Ali, Matius. Estetika: Pengantar Filsafat Seni [Introduction to Art Philosophy]. Sanggar Luxor, 2011.

[10] Ghazali, Abd. Moqsith \& Djohan Effendi. "Merayakan Kebebasan Beragama : Bunga Rampai Menyambut 70 Tahun Djohan Effendi. Penerbit Buku Kompas Jakarta, 2009. 